\title{
Community Economic Empowerment and Improvement of Meru Betiri National Park Area through Strengthening Community Institutional Capacity
}

\author{
$1^{\text {st }}$ Hari Rujito \\ dept. of Agribusiness Management \\ Politeknik Negeri Jember \\ Jember, Indonesia \\ hrujito2@gmail.com
}

\author{
$2^{\text {nd }}$ Merry Muspita Dyah Utami \\ dept.of Animal Science \\ Politeknik Negeri Jember \\ Jember, Indonesia \\ merry.mdu@polije.ac.id
}

\author{
$3^{\text {rd }}$ Hendra Yufit Riskiawan \\ dept. of information technology \\ Politeknik Negeri Jember \\ Jember, Indonesia \\ yufit@polije.ac.id
}

\begin{abstract}
The purpose of this research is to design social engineering through the development of a community institutional organization model with an organizational asset control system that is complemented by a design of the organizational control model that can be calculated to be more suitable to improve community institutional capacity,) Determine superior products in each conservation village in the Meru Betiri National Park Area (MBNP) o that the region's economic empowerment program activities become more focused. This research method uses Participatory Rural Appraisal approach followed by Focus Group Discussion and community consultation in order to get an organizational system model that is more suitable for the people of TNMB area. Location of the research in conservation villages around the national park is right, namely Wonoasri, Curahnongko, Andongrejo, and Sanenrejo. The research results obtained in organizational objectives in the form of outputs and indicators of the success of community organization institutional development, organizational control checklist review, review items control group organizational conditions, checklist control rules, organizational development checklist, product identification the specialty is in each conservation village in the MBNP area and the development technology needs to increase the economic income of the community.
\end{abstract}

Key words: institutional capacity, control asset, conservation village, PRA

\section{INTRODUCTION}

The Meru Betiri National Park (MBNP) rehabilitation partnership program involving the surrounding community has been started since the beginning of 2000 and has now been running for more than 14 years. However, the achievement of vegetation plant growth targets in the MBNP rehabilitation area is still not in line with expectations.

Likewise, security disturbances in the form of forest encroachment and theft of forest wood in MBNP are still common. The not yet optimal economic empowerment of the community around the area and the lack of development of community organization institutions are believed to be one of the causes of ineffective rehabilitation and the emergence of security threats in the MBNP area. Although all this time there has been coaching and the provision of capital assistance by the MBNP Center, the assistance is not able to develop the community's economy. Based on the research shows that the community empowerment model that has been carried out so far has not been able to develop the independence of the community, both individually and organizationally.

Capital assistance in the form of equipment, seeds, livestock and finances that have been provided to support the efforts of conservation village communities, its development is unclear and felt to be incompatible with the region's natural carrying capacity and market absorption potential.

Community empowerment carried out so far, is more towards the project approach than towards the growth of community self-reliance [1]. With this condition, it is not surprising that the achievement of the MBNP area rehabilitation target and also the increase in the economic income of the community in conservation villages around $800,000 \mathrm{IDR} / \mathrm{month}$ or 9,600,000 IDR/farmers in 2014 targeted by the TNMB Center cannot be achieved.

Similarly, the institutional capacity of communities in each conservation village is also still low. This can be seen from the lack of positive interaction between fellow members of community organizations to be able to solve their own problems as well as being less effective. This can be seen from the fact in the field that the Forest Village Community Institution in the MBNP area whose members consist of rehabilitation partner farmers with hundreds of people has not been able to improve the growth effectiveness of rehabilitation plants and is less able to utilize the potential of its members towards economic activities to take advantage of market opportunities.

Whereas based on the development guide of the Forest Community Institute in 2008 from CIFOR (Center for International Forestry Research), what is meant by Forest Village Community Institutions is an institution by rural communities that are in or around the forest to regulate and fulfill their needs through inaction with forests in social, economic, political and cultural context. 
Based on the UGM Center for Community Forestry Studies reported that the Institute for Socio-Economic Villages in the Village Community played a role in developing businesses to improve community economy. Economic issues are important to note because this has a strong influence on the successful management of forest resources. Village Community Social Institutions, play a role in fostering awareness and supporting the social life of the community around the forest to be of higher quality. Community Social Institutions in the form of social associations in the community, whether formed naturally or because of programs from outside the community.

Therefore, to improve the effectiveness of the rehabilitation of the area and the effectiveness of economic empowerment of the community, it is necessary to do social engineering through the strengthening of existing community organization institutions, but so far less able to play the proper role in developing the potential of members and the community in their environment.

Referring to the forest village community institutions on development experience and also the community empowerment activities that have been carried out by MBNP Institute so far, it shows that program planning initiatives and village community organizations are more top-down than bottom up.

Considering that one of the main stakeholders who showed the success of community empowerment around the forest the National Park was a group of people in the community who were the targets of empowerment as well as supporting the National Park conservation program [2] then exploring ideas and inputs and initiatives from community groups, through involving them in program development, will improve the effectiveness of regional rehabilitation and community economic empowerment. The method that involves the community to participate in the preparation of the program is the Participatory Rural Appraisal (PRA) model [3]

The qualitative method of Participatory Rural Appraisal model is a participatory model that is most often used to empower communities both in rural and urban area [4] The background to the use of participation is that programs, projects or community empowerment that come from above or from outside the community often fail because they are not suitable for the needs of local communities.

Based on what is stated above, the research idea using a combination of quantitative methods and qualitative methods needs to be done in order to utilize and optimize the strength of this research, while minimizing its weaknesses [2]. The integration of qualitative and quantitative methods can meet the accuracy requirements of quantitative research, and utilize the depth of qualitative research.

Good collaboration with local communities for the management of the National Park is needed in order to provide good results. As reported by [5] and [6] that in Zimbabwe the collaboration between the managers of Hwange National Park and the people around the area, resulted in good management and reduced conflict with residents. Meanwhile, community empowerment through community-based projects is very effective in improving the lives of poor people in Nigerian villages through increasing productive assets, increasing community income and increasing the welfare of villagers in general in Nigeria. In order for a community-based development approach to be effective in reducing poverty, it must be carefully planned and monitored.

In fact, [7] reported the management of National Parks in six countries in South Africa, namely in Botswana, Malawi, Namibia, South Africa, Zambia and Zimbabwe through the involvement of the surrounding communities in their ecotourism has succeeded in increasing the income of the surrounding communities, increasing employment opportunities, and reducing poverty absolute, improve the socio-economic development of local communities and improve the welfare of people in these countries. Therefore [8] reported that related to the management of the National Park, the government should nationally and internationally also have policies that lead to the involvement of the community in reducing poverty and eliminating the causes.

There are models of national park management in several places in the world to serve as comparative studies in an effort to improve national park management. Based on the experience of managing the national park shows that the involvement of the surrounding community to help manage national parks can be done through several alternative approaches, including

Adaptive Management [9] collaborative management [10], and adaptive co-management [11] which is a general concept of national park management based on the framework of ecological and social systems in the region [12]. The managers acknowledge that there is a need to consider local ecological aspects and social dynamics in the national park area [13] and need to adopt an interdisciplinary approach. Nevertheless, national park managers acknowledge the uncertainty and difficulties in predicting the ecological and social dynamics that occur [14].

The expected results of this study such as find Organizational Structure, find out organizational goals, outputs and indicators of development of Community Organization Institutions in the MBNP area, review checklist, organization and community group control, item Review of Controlling Condition of Farmer Organization Groups, Review Checklist controls the rules of play, Review Checklist and identification of typical superior products in each conservation village in the MBNP area accompanied by technological requirements for its development in order to increase community economic income.

The purpose of this study was to design improvements to the institutional organizational system model of the MBNP area, and the development of an organizational asset control system through the design of an organizational model of organizational systems and organizational control evaluation. With a model of a community institutional organization system designed according to the needs of the community in the MBNP area, it is hoped that it can increase the institutional capacity of the village community concerned. 


\section{RESEARCH AND METHODS}

The participants in this study consisted of several parties including farmers participating in the MBNP rehabilitation partnership in Andongrejo village, Curahnongko village, Wonoasri village, and Sanenrejo village by conducting community consultation in each village wherein each community consultation, rehabilitation partner farmers represented 35 people.

The MBNP representatives by the Field Extension Officer and the Forest Police serving in the village concerned, and the Village or village community outside the participants of the rehabilitation partnership program, in this case by local community leaders and village officials.

The data and information for PRA activities related to organizational systems are qualitative data, while AHP analysis requires quantitative data on conservation results from the opinions of competent experts or stakeholders on various matters related to superior product needs. To identify community problems in each village of MBNP (Wonoasri, Sanenrejo, Curahnongko, and Andongrejo) through the Participatory Rural Appraisal Model, the following steps are taken: the community in the MBNP area is seen as the subject who is most aware of their own problems and needs, identifying the problem, the people of the MBNP area who were involved in community empowerment were asked to convey the problems they had faced in the activities of community empowerment, selecting problems, presenting results, conducting reviews, and developing improvement plan, and together with community members who are members of community group organizations, they are asked to develop a model of the group organization system that they agree on together to improve the existing group organization system.

The researcher tried to put his position as an insider instead of an outsider because that was one of the members of the research team who came from the TNMB Office assisted by the assistants who assisted the community daily. The application of the PRA method in this study in order to obtain accurate information as a basis for the preparation of the system model of the community group organization system.

The implementation of PRA is carried out in each MDK village (Andongrejo Village, Curahnongko Village, Wonoasri Village, and Sanenrejo Village) until later an appropriate organizational system model is obtained for the village community groups concerned. Researchers and facilitators of community empowerment in the TNMB area position themselves as insiders by mingling and collaborating in community groups.

The goal of this PRA activity is to obtain a model for improving the organizational system of the target village community groups so that through improvements to the organizational system it can generate community independence and self-sufficiency.

\section{RESUlts AND Discussion}

Criticism of the results of research results obtained through PRA activities as mentioned above can be presented as follows:

\section{A. The review description checklist of objectives and outputs as well as the success indicators.}

The main task of Forestry Counseling Institutions for the Community (FCC) is to formulate and establish policies and sanctions in a democratic and participatory manner. Organizing the community to jointly formulate a vision, mission and strategic plan that monitors and controls the implementation of control decisions. Encourage participatory processes from aspiration exploration, selfhelp mapping or needs assessment, monitoring and evaluation planning.

In the empowerment principle, the best community groups are groups that are indeed born from the needs and awareness of the people themselves. Managed and developed using mainly the resources in the community.

Self-Help Groups are a group of people who unite themselves voluntarily in groups due to a unifying bond, namely the existence of a common vision, interests, and needs so that the group has the same goals to be achieved. coordinate program management received by the community and program implementers. Monitor and provide input to improve local government program policies. Ensure the participation of various elements of society, especially rehabilitation farmers. Building public transparency, especially from outside parties. This institution is expected to act as a controller

\section{B. Review}

Item points for Controlling the Condition of Group Organizations of the community were prepared based on the need to increase the effectiveness of the organization of the community which had so far been felt to be ineffective. With the review checklist designed, it is expected that the involvement, participation, and democratization of community members can be channeled properly.

\section{Checklist for Group Play Rules}

The Checklist for Group Play Rules arranged based on the need for sustainability and development of perceived assets is very low. So far, capital assistance in the form of money, livestock or equipment that has been provided for more than fourteen years to the people in the MBNP area has not succeeded in growing the economic independence of the community but instead makes the community addicted to being given continuous assistance.

The development of assets in the form of capital or equipment provided to the public is not clear in its development. To overcome this, it is necessary to formulate rules of the game, for members of organizations who want to use or borrow the capital. For, example the clarity of the mechanism of return of equipment/livestock borrowed with the aim of rolling capital to other residents is effective. As for borrowing money, the responsibility of fellow group 
members must take responsibility so that each group member controls the return of money made by other members.

\section{Review Checklist Item of Results of Development}

The Review checklist item of development is designed based on the needs of the formation of rehabilitation farmer community groups by the Taman Meru Betiri Institute.

This review checklist is to monitor and evaluate the extent to which the effectiveness of the organizational system that has been carried out by the community members, how the administrative conditions, and how big the development of capital and assets of the organization, as well as the development of the quantity and quality of farmer community groups members, in this case under the coordination of community self-reliance institution.

\section{CONCLUSION}

The research results obtained The form of outputs and indicators of the success of community organization institutional development, organizational control checklist review, review items control group organizational conditions, checklist control rules, organizational development checklist, product identification the specialty is in each conservation village, and the development technology needs to increase the economic income of the community

\section{ACKNOWLEDGMENT}

The authors would like to express our sincere gratitude to Ministry of Research and Higher Education for funding the research and Politeknik Negeri Jember for grant the paper to present on International Conference on Social Science in Bali, Indonesia

\section{REFERENCES}

S. Paul, Community participation in development projects. World Bank Washington, DC, 1987.

[2] I. Fatima, W. Windia, and K. Suamba, "Agroecotourism Development for Community Empowerment and Strengthening Social Capital in Pemo Village, Kelimutu Sub-District, Ende District, Indonesia."

[3] H. Rujito, "PEMBERDAYAAN EKONOMI MASYARAKAT MELALUI PENGEMBANGAN MODEL DESA KONSERVASI DAN EKOWISATA DI KAWASAN TAMAN NASIONAL MERU BETIRI," UNEJ e-Proceeding, pp. 569-587, 2016.

K. Adimihardja and $\mathrm{H}$. Hikmat, 'Participatory research appraisal'dalam pelaksanaan pengabdian kepada masyarakat: modul latihan. Humaniora Utama Press (HUP), 2001.

[5] A. Perrotton, M. de Garine-Wichatitsky, H. Valls-Fox, and C. Le Page, "My cattle and your park: codesigning a role-playing game with rural communities to promote multistakeholder dialogue at the edge of protected areas," Ecol. Soc., vol. 22, no. 1, 2017.
O. V. Anietem and A. L. Abiodun, "Community driven development (CDD) and rural poverty alleviation in Nigeria: A Bottom-Up Development Approach," in International Conference on Trends in Economics, Humanities and Management (ICTEHM'15) March, 2015, pp. 27-28.

[7] S. L. Snyman, "The role of tourism employment in poverty reduction and community perceptions of conservation and tourism in southern Africa," J. Sustain. Tour., vol. 20, no. 3, pp. 395-416, 2012

[8] M. Braasch, L. García-Barrios, S. Cortina-Villar, E. HuberSannwald, and N. Ramírez-Marcial, "TRUE GRASP: Actors visualize and explore hidden limitations of an apparent win-win land management strategy in a MAB reserve," Environ. Model. Softw., vol. 105, pp. 153-170, 2018.

[9] H. E. Birgé, C. R. Allen, A. S. Garmestani, and K. L. Pope, "Adaptive management for ecosystem services," J. Environ. Manage., vol. 183, pp. 343-352, 2016.

[10] C. Ansell and A. Gash, "Collaborative governance in theory and practice," J. public Adm. Res. theory, vol. 18, no. 4, pp. 543-571, 2008.

[11] C. Fabricius and B. Currie, "Adaptive co-management," in Adaptive management of social-ecological systems, Springer, 2015, pp. 147-179.

[12] A. S. Garmestani, C. R. Allen, and H. Cabezas, "Panarchy, adaptive management and governance: policy options for building resilience," Neb. L. Rev., vol. 87, p. 1036, 2008.

[13] M. D. McGinnis and E. Ostrom, "Social-ecological system framework: initial changes and continuing challenges," Ecol. Soc., vol. 19, no. 2, 2014.

[14] R. Mathevet, J. D. Thompson, C. Folke, and F. S. Chapin, "Protected areas and their surrounding territory: socioecological systems in the context of ecological solidarity," Ecol. Appl., vol. 26, no. 1, pp. 5-16, 2016. 